\title{
Lise Öğrencilerine Özgü Matematik Kaygısı ve Matematik Kaygısı Ölçeğinin (MKÖ)'nin Uygulanmasına Dair Bir Değerlendirme
}

\author{
Anxiety of Mathematic on High School Students and an Assessment About Implementation \\ of Math Anxiety Scale
}

\section{Zeliha KOÇER*}

\section{Geliş Tarihi: 13.02.2019 占 Kabul Tarihi: 06.05.2019 䊎 $\quad$ Yayın Tarihi: 01.07.2019}

\section{Özet}

$\mathrm{Bu}$ çalışma; öğrencilerde görülen matematik kaygısının seviyesini tespit etmede kullanılan daha önce geliştirilmiş Matematik Kaygı Ölçeğini kullanmak ve ilerleyen dönemde yapılan norm çalışmalarına temel oluşturacak bilgilere ulaşmak amaciyla yapılmıştır. Çalışma lise öğrencilerini kapsamaktadır. Onların matematiğe olan kaygılarında sınıf düzeyi, bölüm, cinsiyet, matematik dersi son sınav notu bakımından anlamlı bir değişiklik olup olmadığını araştırmaktadır. Çalışmada MKÖ Matematik Kaygısı Ölçeği veri toplama aracı olarak kullanılmıştır. Çalışmanın örneklemi özel bir lisede öğrenim gören 90 öğrenciden oluşmaktadır. Uygulama 2018-2019 eğitim-öğretim yılının birinci döneminde yapılmıştır. ANOVA ve T-Testi hipotezlerin testi için kullanılmıştır. Araştırma sonucunda istatistiksel olarak öğrencilerin branşı, cinsiyeti ile yaşadıkları matematik kaygısı arasında anlamlı bir fark bulunmamıştır. Fakat öğrencilerin matematik dersi sınav notu ve sinıf düzeyleri ile matematik kaygıları arasında istatistiksel olarak anlamlı bir fark olduğu belirlenmiştir

Anahtar Kelimeler: Lise öğrencileri, matematik, matematik kaygısı, kaygı ölçeği

\begin{abstract}
This work; The aim of this study was to use the previously developed Math Anxiety Scale used to determine the level of math anxiety observed in the students and to reach the information that will form the basis for the norm studies in the following period. The study covers high school students. They investigate whether there is a significant change in grade level, branch, gender, mathematics final exam grade in their anxiety about mathematics. In the study, the MRQ Mathematics Anxiety Scale was used as data collection tool.The sample of the study is 90 students studying at a private high school. The first period of 2018-2019 academic year was applied. ANOVA and T-Test are preferred for testing hypotheses. As a result of the study, statistically significant difference was not observed between the students' branch, gender and math anxiety. However, it was observed that there was a significant difference in mathematics anxiety of students according to grade of mathematics final exam grade and grade levels.
\end{abstract}

Keywords: Anxiety scale, high school students, mathematics, math anxiety

\footnotetext{
*Yüksek lisans öğrencisi, Kocaeli Üniversitesi, Matematik Bölümü, zelihakocer92@gmail.com
} 


\section{Giriş}

Matematik, kendine has içeriği, yapısı ve sistemi ile eğitim ve öğretim alanında önemli bir yere sahiptir. Ayrıca tüm bilimlere katkı sunan ve yaşamın her yerinde işlev kazanan özgün bir bilim olmakla birlikte aynı zamanda toplumsal gelişmeye de fayda sağlayan bir bilim dalıdır (Üldaş, 2005).

Matematik biliminin, eğitime nüfus etmesi, okullarda, her sınıf düzeyinde ders olarak okutulması toplumların sürekli ilerleme ve gelişme ilkesi ile yakından ilişkilidir. Toplumların ilerlemesi, toplumu oluşturan bireylerin kaliteli eğitimlerden geçmesi ile mümkündür. Sadece kural ve ezberden ibaret olarak tanitılan, günlük yaşamda kullanım alanının olmadığı düşünülen matematik, müfredatta yer alan bir ders olarak değil de insanların zihinsel gelişimi için gerekli bir disiplin ve uğraşıldığında keşfedilecek birçok yönü olan bir bilim dalı olarak ele alındığında, eğitimin ne denli önemli bir parçası olduğu gerçeği yadsınamaz (Üldaş, 2005).

Matematik sayesinde insan düşünce bakımından çeşitlilik, mükemmellik, esneklik gibi özellikler kazanır. Bu özellikler insan beynindeki işleyiş tarzıyla doğal bir uyum gösterir. Oysaki çoğu insan matematik öğrenimi sırasında beyindeki sağlıklı gelişim ve işleyişin farkında değildir. Bu durum beyin için elzem bir faaliyettir. Etraftan matematik hakkında yanlış bilgiler, tavır ve önyargılar, okul yaşantısında edinilen olumsuz durumlarla bu gerekli farkındalığın eksikliği birleşince matematiğin hayattan çıkarılması, reddedilmesi isteği başlar. Bu olumsuzluk en başta kişide matematikten kaçma gibi davranışlar ortaya çıkarmasıyla birlikte kişide meslek seçimi yaparken onu sınırlandıracak paralelde tercihler yapmaya, onun performansını düşürüp huzursuzluk, stres, baskı gibi matematik eksenli bir dizi negatif davranış ve duygunun ortaya çıkmasına sebep olur. Bu psikoloji ile bağlantısı olan, matematik kaygısı şeklinde adlandırılan, aynı zamanda bu araştırmanın ana konusu olan bir sorundur (Üldaş, 2005).

Matematik endişesi, kaygısı "matematikle uğraşırken fiziksel belirtilerin yanında ortaya çıkan korku, endişe, asabilik ve sinirlilik duyguları" olarak tanımlanabilir (Fennema ve Sherman 1976). Başka bir deyişle "sayılarla uğraşma sonucu günlük hayat ve akademik problemleri çözmeye engel olan korku ve endişe" şeklinde adlandırılabilir (Richardson ve Suinn 1972) Detaylı bir tanım olarak "matematik problemi çözen kişilerde artan panik, işlevsizleşme, çaresizlik ve akıl karışıklığ1" olarak ele alınabilir (Tobias ve Weissbrod 1980). Matematik kaygısının başka bir belirtisinin de matematikten kaçınma, başka konulara yönelme ve yoğunlaşma görüldüğü ileri sürülmüştür (Hendel ve Davis 1978).

Matematik kaygısı üzerine yapılan çalışmalar incelendiğinde matematik kaygısının akademik başarı üzerinde olumsuz yönde etkisi olduğu belirlenmiştir. (Betz, 1978; Crawford, 1980; Engelhard, 1990; Erol, 1989; Rounds ve Hendel, 1980; Satake ve Amato, 1995; Suinn, Taylor ve Edwards, 1988; Tobias ve Weissbrod, 1980). 
Matematik kaygısını saptamaya yönelik yapılan bu çalışmalarda en çok kullanılan ölçekler Suinn ve Richardson' un geliştirdiği Matematik Kaygısı Değerlendirme Ölçeği (MARS) (Richardson ve Suinn 1972) ve Fennema ve Sherman tarafından geliştirilmiş Matematik Kaygı (MAS) Ölçeğidir (Fennema ve Sherman 1976).

Tüm bu yapılan çalışmaların ışığında araştırmanın önemi ve sağlayabileceği yararları şu şekilde sıralayabiliriz:

1. Lise öğrencilerinin matematik kaygı seviyelerini belirleyerek, kayg1 taşıyanlar için tedbirler alınabilmesi konusunda katkı sunacaktır.

2. Matematik kaygısı nedeniyle akademik performans gösteremeyen öğrencilerin, bilinçli öğretmenlerce fark edilip, kaygıyı önleyici veya azaltıcı yönde destek olunmasına katkı sağlayacaktır.

3. Matematik kaygısının ve ilişkili olduğu faktörlerin anlaşılması ile toplumun kaliteli bir eğitim alarak gelişiminin sağlanması adına eğitimle ilgili gerekli önlemlerin alınması açısından bilimsel bir temel sağlayacaktır.

Matematik Kaygısı Ölçeği çok sayıda araştırmada kullanılmıştır (Erktin, 1993; Erktin, 1994; Erktin ve Küçük 1999; Erktin, Demir ve Gülşen, 2000; Erktin, Dönmez ve Özel, 2006; Erol, 1989). Yine bu çalışmada kullanılan Matematik Kaygısı Ölçeğinin (Erol, 1989) bir örneklemde denenmesi ve bu ölçek yardımı ile lise öğrencilerinin matematik kaygılarının çeşitli değişkenler açısından sınanması amacıyla aşağıdaki sorulara cevap aranacak şekilde yapılmıştır.

1. Lise öğrencilerinin matematik kaygıları hangi düzeydedir?

2. Lise öğrencilerinin matematik kaygılarının çeşitli değişkenler açısından incelenmesine yönelik amaçlar:

a. Öğrencilerin cinsiyet durumuna göre matematik kaygı seviyeleri farklılaşmakta mıdır?

b. Öğrencilerin bölümlerine göre matematik kaygı seviyeleri farklılaşmakta midir?

c. Öğrencilerin sınıf durumuna göre matematik kaygı seviyeleri farklılaşmakta mıdır?

d. Öğrencilerin aldığı matematik notuna göre matematik kaygı seviyeleri farklılaşmakta mıdır?

\section{Yöntem}

Araştırma tarama modelinde yapılmıştır. Araştırma örneklemi olarak seçilen, İzmit'te bir özel lisede okuyan 30'u (\%33) k1z, 60'1 (\%67) erkek toplam 90 öğrenciye Matematik Kaygısı Ölçeği uygulanmıştır. Anketi cevaplayan öğrencilerin 2 tanesi (\%2) dokuzuncu sinıf, 13 tanesi (\%14) onuncu sinıf, 17 tanesi (\%19) on birinci sinıf ve 58 tanesi (\%65) on ikinci sınıf öğrencisidir. Bu 90 öğrencinin 69 tanesi (\%77) sayısal, 21 tanesi (\%23) eşit ağırlık bölümündedir. 


\section{Veri toplama araçları}

Erktin, Dönmez ve Özel, (2006) tarafından geliştirilen Matematik kaygısı ölçeği MKÖ Matematik Kaygısı Ölçeği dörtlü likert tipinde 45 sorudan oluşmaktadır. Ölçekteki sorular örnek alınan çalışmada yapılan faktör analizi sonucu 4 alt boyuta ayrılmıştır. Bunlar; 1. Matematik Testi ve Testin Değerlendirilmesi Kayg1sı, 2. Matematiğe Yönelik Kayg1, 3. Gündelik Yaşamdaki Matematiksel Kayg1 4. Matematik Hususunda Özgüven Eksikliğidir. Araştırmada MKÖ Matematik Kaygısı Ölçeğinden ziyade öğrencilerin demografik özelliklerini belirlemek amaciyla doğum tarihi, cinsiyet, okul adı, sınıf ve aldığı son matematik notu bilgilerini içeren bir anket daha uygulanmıştır.

\section{Verilerin analizi, geçerlik ve güvenirlik}

Araştırmadan elde edilen verilerin analizinde SPSS istatistik programından yararlanılmıştır. Ölçeğin güvenirliğine ilişkin Cronbach alfa güvenirlik katsayısı ve normal dağıldığına ilişkin çarpıklık ve basıklık değerleri hesaplanmıştır.

Cronbach alfa katsayısı yüksek olan ölçekteki maddelerin birbirleriyle tutarlı bir o kadar da aynı özelliği ölçen maddelerden meydana geldiği yorumu yapılır. Cronbach alfa için ölçekle ilgili aşağıdaki şekilde;

- $0<\alpha<0.40$ ise ölçek güvenilir değil

- $0.40<\alpha<0.60$ ise ölçek düşük güvenilirlikte

- $0.60<\alpha<0.80$ ise ölçek oldukça güvenilir

- $0.80<\alpha<1.00$ ise ölçek yüksek güvenilirlikte

, yorumları yapılabilir (Yıldız ve Uzunsakal, 2018).

Buna göre ölçek üzerinde yapılan ilk güvenilirlik çalışmasında Cronbach alfa katsayısı 0,91 olarak yüksek güvenirlikte bulunmuştur (Erol, 1989). Aynı şekilde MKÖ Matematik Kaygısı Ölçeğinin bu çalışmanın örneklemindeki güvenirliğini ölçmek amacıyla elde edilen Cronbach Alpha iç tutarlılık katsayısı ise $\alpha=0,89$ olarak tespit edilmiştir. Bu katsayı ile ölçeğin çok güvenilir bir ölçek olduğu görülmektedir. Ölçeğin alt boyutlarının güvenirliğini irdelediğimizde;

- Sınav ve değerlendirilmesi; birinci bölüm 17 maddeden meydana gelmektedir. Bu boyuttaki maddeler için Cronbach Alpha katsayısı 0,89 olarak hesaplanmıştır.

- Matematik dersi; ikinci bölüm de yine 17 maddeden meydana gelmektedir. $\mathrm{Bu}$ boyuttaki maddeler için Cronbach Alpha katsayısı 0,64 olarak hesaplanmıştır.

- Gündelik yaşamda matematiğin kullanımı; üçüncü bölümde 7 maddeden meydana gelmektedir. Bu boyuttaki maddeler için Cronbach Alpha katsayısı 0,87 olarak hesaplanmıştır. 
- Matematik konusunda kendini yeterli hissetmesi; dördüncü bölüm ise 4 maddeden meydana gelmektedir. Bu boyuttaki maddeler için Cronbach's Alpha katsayısı 0,63 olarak hesaplanmıştır.

Verilerin normal dağılıp dağılmadığını saptamak amacıyla normallik testi uygulanmış ve ölçeğin çarpıklık değeri $-0,057$ ve basıklık değeri 0,136 olarak bulunmuştur. Bu değerler $-1,5$ ve 1,5 arasındadır ve buna bağlı olarak elde edilen sonuçlar normal dağılım sergilemiştir (Tabachnick ve Fidell 2013). Bu yüzden verilerin analizinde parametrik testler olan t-testi ve Oneway Anova testlerine başvurulmuştur.

\section{Bulgular}

90 tane öğrenciden oluşan örneklem Matematik Kaygısı Ölçeğindeki (MKÖ) soruların hepsine cevap vermiştir. Ulaşılan sonuçlara göre ortalama puan 94,23, standart sapma puanı ise 16,43 olarak elde edilmiştir. Ölçekte ki en yüksek puan 136, en düşük puanın ise $51^{\prime}$ dir.

Tablo 1. MKÖ Boyutları

\begin{tabular}{llll}
\hline & n & $\overline{\mathrm{X}}$ & ss \\
\hline MKÖ Matematik Kaygısı Ölçeği & 90 & 94,23 & 16,43 \\
\hline $\begin{array}{l}\text { Matematik sınavı ve değerlendirilme } \\
\text { kaygısı }\end{array}$ & 90 & 37,09 & 9,14 \\
\hline Matematik dersine ilişkin kaygı & 90 & 38,47 & 5,89 \\
\hline Günlük yaşamda matematik kaygısı & 90 & 11,47 & 4,08 \\
\hline Matematik konusunda özgüven eksikliği & 90 & 7,2 & 2,46 \\
\hline
\end{tabular}

Matematik Kaygısı Ölçeğinden en düşük 45, en yüksek ise 180 puan alınabileceğine göre, ortalama puanın ise 112,5 bir değer olduğu görülebilir.

Fakat 90 tane öğrencinin ölçeğin hepsini yanıtlamış ve buradan elde edilen bilgilere göre ortalamanın 94,2 standart sapmanın da 16,4 olduğu tespit edilmiştir. Bu örneklemin temsil gücünün yüksek ve yeterli derecede yüksek olduğunu düşünürsek matematik kaygısını şöyle derecelendirebiliriz:

- 45-77 Düşük derecede, matematik kaygılı

- 78-109 Normal derecede, matematik kaygilı

- 110-128 Kaygilı derecede matematik kaygılı

- 129-180 Yüksek derecede, matematik kaygılı 
Ölçek incelendiğinde; ortalama, en düşük değere fazla yakın olmasından dolayı, yüksek dereceli matematik kaygısına belirlenmiş olan aralık değeri oldukça geniş tutulmuştur.

Lise öğrencilerinin matematik kaygısına yönelik oluşturulan 1. Matematik Testi ve Testin Değerlendirilmesi Kaygısı, 2. Matematiğe Yönelik Kaygı, 3. Gündelik Yaşamdaki Matematiksel Kaygı, 4. Matematik Hususunda Özgüven Eksikliği gibi alt boyutlarının; sınıf düzeyi, cinsiyet, bölüm ve son matematik sınav notu değişkenlerine göre anlamlı bir farklılık yaratıp yaratmadığını saptamak için uygulanan çalışmada, ulaşılan sonuçlar araştırma sorularına uygun olarak tablolarla gösterilmiştir.

Tablo 2. Öğrencilerin Cinsiyete Göre Matematiğe Karşı Duydukları Kaygının T-Testi Sonuçları

\begin{tabular}{|c|c|c|c|c|c|}
\hline & Cinsiyet & $\mathbf{n}$ & $\bar{X}$ & ss & $\mathrm{p}$ \\
\hline \multirow{2}{*}{$\begin{array}{l}\text { 1. Matematik Testi ve Testin } \\
\text { Değerlendirilmesi Kaygısı }\end{array}$} & Erkek & 60 & 2,1262 & ,57632 & \multirow{2}{*}{, 166 } \\
\hline & Kadın & 30 & 2,2932 & ,43893 & \\
\hline \multirow{2}{*}{ 2. Matematiğe Yönelik Kayg1 } & Erkek & 60 & 2,2711 & ,39035 & \multirow{2}{*}{,752 } \\
\hline & Kadın & 30 & 2,2465 & 24038 & \\
\hline \multirow{2}{*}{$\begin{array}{l}\text { 3. Gündelik Yaşamdaki } \\
\text { Matematiksel Kayg1 }\end{array}$} & Erkek & 60 & 1,6333 &, 59478 & \multirow{2}{*}{,900 } \\
\hline & Kadın & 30 & 1,6499 &, 56777 & \\
\hline \multirow{2}{*}{$\begin{array}{l}\text { 4. Matematik Hususunda } \\
\text { Özgüven Eksikliği }\end{array}$} & Erkek & 60 & 1,8625 & ,62339 & \multirow{2}{*}{,174 } \\
\hline & Kadın & 30 & 1,6750 &, 58777 & \\
\hline
\end{tabular}

Tablo 2 incelendiğinde matematiğe karşı duyulan kaygının öğrencilerin cinsiyetine göre anlamlı bir farklılık göstermediği görülmüştür ( $p>.05)$.

Tablo 3. Öğrencilerin Bölümüne Göre Matematiğe Karşı Duydukları Kaygııın T-Testi Sonuçları

\begin{tabular}{lccccc}
\hline & Bölüm & $\mathbf{n}$ & $\bar{X}$ & ss & p \\
\hline $\begin{array}{l}\text { 1. Matematik Testi ve Testin } \\
\text { Değerlendirilmesi Kaygısı }\end{array}$ & SA & 69 & 2,1287 &, 52550 &, 089 \\
\hline & EA & 21 & 2,3565 &, 55353 &, 271 \\
2. Matematiğe Yönelik Kayg1 & SA & 69 & 2,2406 &, 36072 &, 29006 \\
\hline 3. Gündelik Yaşamdaki & EA & 21 & 2,3361 &, 272 \\
Matematiksel Kaygi & SA & 69 & 1,6014 &, 55547 &, 66445 \\
\hline
\end{tabular}




\begin{tabular}{llllll}
\hline 4. Matematik Hususunda & SA & 69 & 1,7609 &, 62343 & \multirow{2}{*}{, 276} \\
Özgüven Eksikliği & EA & 21 & 1,9286 &, 58172 & \\
\hline
\end{tabular}

Tablo 3 incelendiğinde öğrencilerin matematiğe karşı duydukları kaygının bölüme göre anlamlı bir farklılık oluşturmadığı sonucuna ulaşılmıştır ( $p>.05$ ). Tablo 3 'de öğrencilerin sınıf düzeylerine göre matematiğe karşı duydukları kaygıya ilişkin One-way Anova sonuçlarına yer verilmektedir.

Tablo 4. Anova Analizine Göre Öğrencilerin Sınıf Düzeyine Göre Matematiğe Karşı Duydukları Kaygı Arasındaki Sonuçlar

\begin{tabular}{|c|c|c|c|c|c|c|}
\hline & Var K. & $\mathrm{KT}$ & $\mathrm{Sd}$ & KO & f & $\mathbf{p}$ \\
\hline \multirow{3}{*}{$\begin{array}{l}\text { 1. Matematik Testi ve } \\
\text { Testin Değerlendirilmesi } \\
\text { Kaygısı }\end{array}$} & Gruplar arası &, 559 & 3 & 186 & 636 &, 594 \\
\hline & Gruplar içi & 25,183 & 86 & 293 & & \\
\hline & Toplam & 25,741 & 89 & & & \\
\hline \multirow{3}{*}{$\begin{array}{l}\text { 2. Matematiğe Yönelik } \\
\text { Kayg1 }\end{array}$} & Gruplar arası & 1,157 & 3 & ,386 & 3,485 & ,019 \\
\hline & Gruplar içi & 9,520 & 86 & 111 & & \\
\hline & Toplam & 10,678 & 89 & & & \\
\hline \multirow{3}{*}{$\begin{array}{l}\text { 3. Gündelik Yaşamdaki } \\
\text { Matematiksel Kaygı }\end{array}$} & Gruplar arası & 643 & 3 & 214 & 623 & 602 \\
\hline & Gruplar içi & 29,583 & 86 & ,344 & & \\
\hline & Toplam & 30,226 & 89 & & & \\
\hline \multirow{3}{*}{$\begin{array}{l}\text { 4. Matematik Hususunda } \\
\text { Özgüven Eksikliği }\end{array}$} & Gruplar arası & ,434 & 3 & 145 & ,374 & ,772 \\
\hline & Gruplar içi & 33,216 & 86 & ,386 & & \\
\hline & Toplam & 33,650 & 89 & & & \\
\hline
\end{tabular}

Bu sonuçlara göre sınıf düzeyine göre kaygıda yalnızca Matematik Yönelik Kaygı boyutunda anlamlı bir farklılık olduğu belirlenmiştir. $(\mathrm{p}=.019<.05)$. Buna göre 9.sinıf (ort.:2,44) ve 11.sinıf (ort.:2,41) öğrencileri, 12.sınıf (ort.:2,18) öğrencilerine göre matematik dersine karşı daha fazla kaygı duymaktadır.

Sınıf düzeyinin matematik dersine ilişkin kaygı üzerindeki etkisini sayısal olarak saptamak amacıyla yapılan regresyon analizini inceleyelim. 
Tablo 5. Öğrencilerin Sını Düzeyine Göre Matematiğe Yönelik Kaygılarının Regresyon Analizi Sonuçları

\begin{tabular}{|c|c|c|c|c|c|c|}
\hline \multirow{2}{*}{\multicolumn{2}{|c|}{ Model }} & \multicolumn{2}{|c|}{$\begin{array}{c}\text { Standardize Edilmemiş } \\
\text { Katsayılar }\end{array}$} & \multirow{2}{*}{$\begin{array}{c}\begin{array}{c}\text { Standardize Edilmiş } \\
\text { Katsayılar }\end{array} \\
\text { Beta } \\
\end{array}$} & \multirow[b]{2}{*}{$t$} & \multirow[b]{2}{*}{$\mathrm{p}$} \\
\hline & & B & Standart Hata & & & \\
\hline 1 & Sabit & 2,698 & 152 & & $\begin{array}{c}17,75 \\
0\end{array}$ & ,000 \\
\hline & Sinıf düzeyi &,- 126 & ,043 &,- 299 & $-2,940$ & ,004 \\
\hline
\end{tabular}

Bağımlı değişken: Matematiğe Yönelik Kaygı.

Tabloya göre; $\mathrm{Y}=2,698-0.126 * \mathrm{X}$ modeli elde edilir. (X: Sinıf düzeyi, $\mathrm{Y}$ : Matematiğe Yönelik Kaygı). Buna göre öğrencilerin sınıf düzeyi arttıkça matematik dersine ilişkin kaygıları azalabilmektedir.

Tablo 6. Anova Analizine Göre Öğrencilerin Aldığı Son Matematik Notuna Göre Matematiğe Karşı Duydukları Kayğ Arasındaki Sonuçlar

\begin{tabular}{|c|c|c|c|c|c|c|}
\hline & Var K. & KT & Sd & KO & f & $\mathrm{p}$ \\
\hline \multirow{4}{*}{$\begin{array}{l}\text { 1. Matematik Testi ve } \\
\text { Testin Değerlendirilmesi } \\
\text { Kaygısı }\end{array}$} & \multirow{2}{*}{$\begin{array}{l}\text { Gruplar } \\
\text { arası }\end{array}$} & 4,882 & 4 & 1,221 & \multirow[t]{4}{*}{4,974} & \multirow[t]{4}{*}{,001 } \\
\hline & & 20,859 & 85 & 245 & & \\
\hline & Gruplar içi & 25,741 & 89 & & & \\
\hline & Toplam & & & & & \\
\hline \multirow{4}{*}{$\begin{array}{l}\text { 2. Matematiğe Yönelik } \\
\text { Kayg1 }\end{array}$} & \multirow{4}{*}{$\begin{array}{c}\text { Gruplar } \\
\text { arası } \\
\text { Gruplar içi } \\
\text { Toplam }\end{array}$} & ,328 & 4 & ,082 & \multirow[t]{4}{*}{674} & \multirow[t]{4}{*}{ 612 } \\
\hline & & 10,349 & 85 & ,122 & & \\
\hline & & 10,678 & 89 & & & \\
\hline & & & & & & \\
\hline \multirow{4}{*}{$\begin{array}{l}\text { 3. Gündelik Yaşamdaki } \\
\text { Matematiksel Kaygı }\end{array}$} & \multirow{2}{*}{$\begin{array}{c}\text { Gruplar } \\
\text { arası }\end{array}$} & 3,506 & 4 & 877 & \multirow[t]{4}{*}{2,788} & \multirow[t]{4}{*}{,031 } \\
\hline & & 26,720 & 85 &, 314 & & \\
\hline & Gruplar içi & 30,226 & 89 & & & \\
\hline & Toplam & & & & & \\
\hline \multirow{4}{*}{$\begin{array}{l}\text { 4. Matematik Hususunda } \\
\text { Özgüven Eksikliği }\end{array}$} & \multirow{2}{*}{$\begin{array}{l}\text { Gruplar } \\
\text { arası }\end{array}$} & 3,649 & 4 & ,912 & \multirow[t]{4}{*}{2,585} & \multirow[t]{4}{*}{,053 } \\
\hline & & 30,001 & 85 &, 353 & & \\
\hline & Gruplar içi & 33,650 & 89 & & & \\
\hline & Toplam & & & & & \\
\hline
\end{tabular}

Tablo 6'da öğrencilerin matematiğe karşı duydukları kaygının aldığı son matematik notuna bakılarak kıyaslama yapıldığında anlamlı bir farklılık oluştuğu görülmektedir $(\mathrm{p}<.05)$. Tablo 5 incelendiğinde ilk olarak öğrencinin aldı̆̆g son matematik notu ile matematik sinavı ve değerlendirilme kaygısı boyutu arasında 
anlamlı bir farklılık görülmüştür. Buna göre 'kalır' not alan öğrenciler (ort.:2,67) ve 'orta' not alan öğrenciler (ort.:2,48) 'pekiyi' not alan öğrencilere (ort.:1,89) göre daha fazla matematik sınavı ve değerlendirme kaygısı taşımaktadır. Matematik sınavı ve değerlendirme kaygısının öğrencinin aldığı son matematik notu üzerindeki etkisini sayısal olarak saptamak amacıyla yapılan korelasyon ve regresyon analizlerine göre ise;

Tablo 7. Öğrencinin Aldı̆̆ Arasındaki Korelasyon Analizi Sonuçları

\begin{tabular}{lccc}
\hline & & $\begin{array}{c}\text { Öğrencinin aldığı } \\
\text { son matematik notu }\end{array}$ & $\begin{array}{c}\text { Matematik Testi ve Testin } \\
\text { Değerlendirilmesi Kaygısı }\end{array}$ \\
\hline $\begin{array}{l}\text { Öğrencinin aldığı son } \\
\text { matematik notu }\end{array}$ & p.c. & 1 &,$- 377^{*}$ \\
& $\mathrm{p}$ & &, 000 \\
& $\mathrm{n}$ & 90 & 90 \\
\hline Matematik Testi ve Testin & p.c. &,$- 377^{*}$ & 1 \\
Değerlendirilmesi & $\mathrm{p}$ &, 000 & 90 \\
Kaygısı & $\mathrm{n}$ & 90 & \\
\hline
\end{tabular}

*: Negatif yönlü korelasyon ilişkisi.

Tabloya göre korelasyon analizi sonucunda; öğrencinin matematik sınavı ve değerlendirilme kaygısı ile son aldığı matematik notu arasında negatif yönlü bir korelasyon vardir (p.c.: -0,377).

Tablo 8. Öğrencinin Aldı̆̆ı Son Matematik Notu ile Matematik Testi ve Değerlendirilme Kaygısı Arasındaki Regresyon Analizi Sonuçları

\begin{tabular}{|c|c|c|c|c|c|c|}
\hline & \multirow[b]{2}{*}{ Model } & \multicolumn{2}{|c|}{$\begin{array}{c}\text { Standardize Edilmemiş } \\
\text { Katsayılar }\end{array}$} & \multirow{2}{*}{$\begin{array}{c}\begin{array}{c}\text { Standardize Edilmiş } \\
\text { Katsayılar }\end{array} \\
\text { Beta } \\
\end{array}$} & \multirow[b]{2}{*}{$\mathbf{t}$} & \multirow[b]{2}{*}{$\mathbf{p}$} \\
\hline & & B & Standart Hata & & & \\
\hline \multirow[t]{2}{*}{1} & Sabit & 5,553 & ,455 & & 12,200 & ,000 \\
\hline & $\begin{array}{l}\text { Matematik } \\
\text { Testi ve Testin } \\
\text { Değerlendiril } \\
\text { mesi Kaygısı }\end{array}$ &,- 773 & ,203 &,- 377 & $-3,815$ & ,000 \\
\hline
\end{tabular}

Bağımlı değişken: Öğrencinin aldığı son matematik notu.

Regresyon analizi sonucunda; $\mathrm{Y}=5,553-0,773 * \mathrm{X}$ modeli elde edilir. (X: Matematik Testi ve Testin Değerlendirilmesi Kaygısı, Y: Son dönem karnesindeki matematik notu). Sonuç olarak öğrencinin matematik sınavı ve değerlendirilme kaygısı arttıkça matematik sınavından aldığı not düşebilmektedir.

İkinci olarak öğrencinin aldığı son matematik notu ile günlük yaşamda matematik kaygısı boyutu arasında anlamlı bir farklılık görülmüştür. Buna göre 'kalır' not alan öğrenciler (ort.:2,29) 'pekiyi' alan öğrencilere (ort.:1,44) göre daha 
fazla günlük yaşamda matematik kaygısı yaşamaktadır. Korelasyon ve regresyon analizi sonuçlarına baktı̆̆ımızda;

Tablo 9. Öğrencinin Aldığı Son Matematik Notu ile Gündelik Yaşamdaki Matematiksel Kaygısı Arasındaki Korelasyon Analizi Sonuçları

\begin{tabular}{lccc}
\hline & & $\begin{array}{c}\text { Öğrencinin aldı̆̆ son } \\
\text { matematik notu }\end{array}$ & $\begin{array}{c}\text { Gündelik Yaşamdaki } \\
\text { Matematiksel Kaygı }\end{array}$ \\
\hline $\begin{array}{l}\text { Öğrencinin aldığ1 son } \\
\text { matematik notu }\end{array}$ & p.c. & 1 &,$- 258^{*}$ \\
& p & &, 014 \\
& n & 90 & 90 \\
\hline Gündelik Yaşamdaki & p.c. &,$- 258^{*}$ & 1 \\
Matematiksel Kayg1 & & & \\
& p &, 014 & 90 \\
\hline
\end{tabular}

*: Negatif yönlü korelasyon ilişkisi.

Korelasyon analizi sonucunda; öğrencinin günlük yaşamda matematik kaygısı ile son aldığı matematik notu arasında negatif yönlü bir korelasyon vardır (p.c.: $0,258)$.

Regresyon analizi sonucunda;

Tablo 10. Öğrencinin Aldığı Son Matematik Notu ile Gündelik Yaşamdaki Matematiksel Kaygısı Arasındaki Regresyon Analizi Sonuçları

\begin{tabular}{|c|c|c|c|c|c|c|}
\hline & \multirow[b]{2}{*}{ Model } & \multicolumn{2}{|c|}{$\begin{array}{c}\text { Standardize Edilmemiş } \\
\text { Katsayılar }\end{array}$} & \multirow{2}{*}{$\begin{array}{c}\begin{array}{c}\text { Standardize } \\
\text { Edilmiş Katsayılar }\end{array} \\
\text { Beta } \\
\end{array}$} & \multirow[b]{2}{*}{$\mathbf{t}$} & \multirow[b]{2}{*}{$\mathbf{p}$} \\
\hline & & B & Standart Hata & & & \\
\hline \multirow[t]{2}{*}{1} & Sabit & 4,667 & ,339 & & 13,764 & 000 \\
\hline & $\begin{array}{l}\text { Gündelik } \\
\text { Yaşamdaki } \\
\text { Matematiksel } \\
\text { Kayg1 }\end{array}$ &,- 488 & 195 &,- 258 & $-2,503$ & ,014 \\
\hline
\end{tabular}

Bağımlı değişken: Öğrencinin aldığı son matematik notu.

$\mathrm{Y}=4,667-0,488 * \mathrm{X}$ modeli elde edilmektedir. (X: Gündelik Yaşamdaki Matematiksel Kaygı, Y: Son dönem karnesindeki matematik notu)

Sonuç olarak öğrencinin günlük yaşamda duyduğu matematik kaygısı matematik sınavından aldığı notu olumsuz olarak etkileyebilmektedir. Kaygı arttıkça aldığı not düşebilir. Alt boyutlar arasındaki ilişkileri saptamak amacıyla yapılan korelasyon ve regresyon analizleri sonuçlarına bakacak olursak; 
Tablo 11. Alt Boyutlar Arasındaki Korelasyon Sonuçları

\begin{tabular}{|c|c|c|c|c|c|}
\hline & & $\begin{array}{l}\text { 1.Matematik Testi } \\
\text { ve Testin } \\
\text { Değerlendirilmesi } \\
\text { Kaygısı }\end{array}$ & $\begin{array}{l}\text { 2.Matematiğe } \\
\text { Yönelik } \\
\text { Kayg1 }\end{array}$ & $\begin{array}{l}\text { 3. Gündelik } \\
\text { Yaşamdaki } \\
\text { Matematiksel } \\
\text { Kayg1 }\end{array}$ & $\begin{array}{l}\text { 4.Matematik } \\
\text { Hususunda } \\
\text { Özgüven } \\
\text { Eksikliği }\end{array}$ \\
\hline \multirow{3}{*}{$\begin{array}{l}\text { 1. Matematik Testi } \\
\text { ve Testin } \\
\text { Değerlendirilmesi } \\
\text { Kaygisı }\end{array}$} & p.c. & 1 & $487^{* * *}$ & , $464^{* * *}$ & ,258* \\
\hline & $\mathrm{p}$ & 90 & 000 & ,000 & ,014 \\
\hline & $\mathrm{n}$ & & 90 & 90 & 90 \\
\hline \multirow{3}{*}{$\begin{array}{l}\text { 2. Matematiğe } \\
\text { Yönelik Kayg1 }\end{array}$} & p.c. &, $487^{* *}$ & 1 & $446^{* *}$ & -,050 \\
\hline & $\mathrm{p}$ & 000 & 90 & ,000 & 639 \\
\hline & $\mathrm{n}$ & 90 & & 90 & 90 \\
\hline \multirow{3}{*}{$\begin{array}{l}\text { 3. Gündelik } \\
\text { Yaşamdaki } \\
\text { Matematiksel } \\
\text { Kayg1 }\end{array}$} & p.c. &, $464^{* * *}$ &, $446^{* *}$ & 1 &, $515^{* *}$ \\
\hline & $\mathrm{p}$ & 000, & 000, & 90 & 000 \\
\hline & $\mathrm{n}$ & 90 & 90 & & 90 \\
\hline \multirow{3}{*}{$\begin{array}{l}\text { 4. Matematik } \\
\text { Hususunda } \\
\text { Özgüven Eksikliği }\end{array}$} & p.c. & $258^{*}$ & -050,- &, $515^{* *}$ & 1 \\
\hline & $\mathrm{p}$ & ,014 & 639 & 000 & 90 \\
\hline & $\mathrm{n}$ & 90 & 90 & 90 & \\
\hline
\end{tabular}

Matematik sınavı ve değerlendirilme kaygısıyla matematik dersine ilişkin kaygı arasında pozitif yönlü bir ilişki vardır (p.c.=0,487). Matematik sınavı ve değerlendirilme kaygısının matematik dersine ilişkin kaygıyı ne kadar etkilediğini saptamak amaciyla yapılan regresyon analizine göre ise;

Tablo 12. Matematik Testi ve Testin Değgerlendirilme Kaygısı ile Matematiğge Yönelik Kaygı Arasındaki Regresyon Analizi Sonuçları

\begin{tabular}{|c|c|c|c|c|c|c|}
\hline & \multirow[b]{2}{*}{ Model } & \multicolumn{2}{|c|}{$\begin{array}{c}\text { Standardize Edilmemiş } \\
\text { Katsayılar }\end{array}$} & \multirow{2}{*}{$\begin{array}{c}\begin{array}{c}\text { Standardize Edilmiş } \\
\text { Katsayılar }\end{array} \\
\text { Beta } \\
\end{array}$} & \multirow[b]{2}{*}{$\mathbf{t}$} & \multirow[b]{2}{*}{$\mathbf{p}$} \\
\hline & & B & Standart Hata & & & \\
\hline \multirow[t]{2}{*}{1} & Sabit & 1,579 & 135 & & 11,719 & ,000 \\
\hline & $\begin{array}{l}\text { Matematik } \\
\text { Testi ve Testin } \\
\text { Değerlendiril } \\
\text { mesi Kaygısı }\end{array}$ & ,314 & ,060 & ,487 & 5,228 & ,000 \\
\hline
\end{tabular}

Bağımlı değişken: Matematiğe yönelik kaygı.

$Y=1,579+0,314^{*} X$ modeli ortaya çıkmıştır. (X: Matematik Testi ve Testin Değerlendirilmesi Kaygısı, Y: Matematiğe Yönelik Kaygı) 
Sonuç olarak öğrencinin matematik sınavı ve değerlendirme kaygısı arttıkça matematik dersine ilişkin kaygısı da buna paralel olarak artabilir. Tersine öğrencinin matematik dersine ilişkin kaygısı azaldığında sınav ve değerlendirmeye karşı olan kaygisı azalabilir.

- Matematik sinavı ve değerlendirilme kaygısı ile günlük yaşamda matematik kaygısı arasında pozitif yönlü bir ilişki vardır (p.c=0,464).

- Matematik sinavı ve değerlendirilme kaygısının günlük yaşamda matematik kaygısını ne kadar etkilediğini saptamak amacıyla yapılan regresyon analizine göre ise;

Tablo 13. Matematik Sınavı ve Değerlendirilme Kaygısı ile Gündelik Yaşamdaki Matematiksel Kaygı Arasındaki Regresyon Analizi Sonuçları

\begin{tabular}{|c|c|c|c|c|c|c|}
\hline & \multirow[b]{2}{*}{ Model } & \multicolumn{2}{|c|}{$\begin{array}{c}\text { Standardize Edilmemiş } \\
\text { Katsayılar }\end{array}$} & \multirow{2}{*}{$\begin{array}{c}\begin{array}{c}\text { Standardize Edilmiş } \\
\text { Katsayılar }\end{array} \\
\text { Beta } \\
\end{array}$} & \multirow[b]{2}{*}{$t$} & \multirow[b]{2}{*}{$p$} \\
\hline & & B & Standart Hata & & & \\
\hline \multirow[t]{2}{*}{1} & Sabit & ,542 & 230 & & 2,358 & 021 \\
\hline & $\begin{array}{l}\text { Matematik } \\
\text { Testi ve Testin } \\
\text { Değerlendiril } \\
\text { mesi Kaygısı }\end{array}$ & ,503 & 102 & ,464 & 4,913 & ,000 \\
\hline
\end{tabular}

Bağımlı değişken: Gündelik Yaşamdaki Matematiksel Kaygı.

$\mathrm{Y}=0,542+0,503^{*} \mathrm{X}$ modeli ortaya çıkmıştır. (X: Matematik Testi ve Testin Değerlendirilmesi Kaygısı, Y: Gündelik Yaşamdaki Matematiksel Kaygı)

Sonuç olarak öğrencinin matematik sınavı ve değerlendirilmesine olan kaygısı arttıkça gündelik yaşamdaki matematik kaygısı da artabilir.

- Matematik sinavi ve değerlendirilme kaygısı ile matematik konusunda özgüven eksikliği arasında pozitif yönlü bir ilişki vardır (p.c. $=0,258$ ).

- Matematik sınavı ve değerlendirilme kaygısının matematik konusunda kendine güveni ne kadar etkilediğini saptamak amaciyla yapılan regresyon analizine göre ise;

Tablo 14. Matematik Sınavı ve Değerlendirilme Kaygısı ile Matematik Hususunda Özgüven Eksikliği Arasındaki Regresyon Analizi Sonuçları

\begin{tabular}{|c|c|c|c|c|c|c|}
\hline & \multirow[b]{2}{*}{ Model } & \multicolumn{2}{|c|}{$\begin{array}{c}\text { Standardize Edilmemiş } \\
\text { Katsayılar }\end{array}$} & \multirow{2}{*}{$\begin{array}{c}\begin{array}{c}\text { Standardize Edilmiş } \\
\text { Katsayılar }\end{array} \\
\text { Beta }\end{array}$} & \multirow[b]{2}{*}{$t$} & \multirow[b]{2}{*}{ p } \\
\hline & & B & Standart Hata & & & \\
\hline \multirow[t]{2}{*}{1} & Sabit & 1,156 & ,265 & & 4,371 & ,000 \\
\hline & $\begin{array}{l}\text { Matematik } \\
\text { Testi ve Testin } \\
\text { Değerlendiril } \\
\text { mesi Kaygısı }\end{array}$ & ,295 & ,118 & ,258 & 2,506 & ,000 \\
\hline
\end{tabular}

Bağımlı değişken: Matematik hususunda özgüven eksikliği. 
$\mathrm{Y}=1,156+0,295 * \mathrm{X}$ modeli elde edilir. (X: Matematik Testi ve Testin Değerlendirilmesi Kaygısı, Y: Matematik Hususunda Özgüven Eksikliği)

Sonuç olarak öğrencinin matematik konusunda özgüven eksikliği arttıkça matematik sınavı ve sınava bağlı değerlendirilme kaygısı da artabilir.

- Matematiğe olan kaygı ile gündelik hayattaki matematik kaygısı arasında pozitif yönlü bir ilişki vardır (p.c.=0,446).

- Günlük yaşamda matematik kaygısının matematik dersine ilişkin kaygıyı ne kadar etkilediğini saptamak amacıyla yapılan regresyon analizine göre ise;

Tablo 15. Gündelik Yaşamdaki Matematiksel Kaygı ile Matematiğe Yönelik Kaygı Arasındaki Regresyon Analizi Sonuçları

\begin{tabular}{|c|c|c|c|c|c|c|}
\hline & \multirow[b]{2}{*}{ Model } & \multicolumn{2}{|c|}{$\begin{array}{c}\text { Standardize Edilmemiş } \\
\text { Katsayllar }\end{array}$} & \multirow{2}{*}{$\begin{array}{c}\begin{array}{c}\text { Standardize Edilmiş } \\
\text { Katsayılar }\end{array} \\
\text { Beta } \\
\end{array}$} & \multirow[b]{2}{*}{$\mathbf{t}$} & \multirow[b]{2}{*}{$\mathbf{p}$} \\
\hline & & B & Standart Hata & & & \\
\hline \multirow[t]{2}{*}{1} & Sabit & 1,828 & ,099 & & 18,549 & 000 \\
\hline & $\begin{array}{l}\text { Gündelik } \\
\text { Yaşamdaki } \\
\text { Matematiksel } \\
\text { Kayg1 }\end{array}$ & ,265 & ,057 & ,258 & 4,681 & ,000 \\
\hline
\end{tabular}

Bağımlı değişken: Matematiğe yönelik kaygı.

$Y=1,828+0,265 * X$ modeli elde edilir. (X: Gündelik Yaşamdaki Matematiksel Kayg1, Y: Matematiğe Yönelik Kayg1)

Sonuç olarak matematik dersine ilişkin duyulan kaygı arttıkça günlük yaşamda hissedilen matematik kaygısı da paralel şekilde artabilir.

- Günlük hayatta matematiğe duyulan kayg1 ile matematik hususunda özgüven eksikliği arasında pozitif ilerleyen bir ilişki vardır (p.c.=0,515).

- Matematik hususunda özgüven eksikliğinin günlük yaşamda matematik kaygısını ne kadar etkilediğini saptamak amacıyla yapılan regresyon analizine göre ise;

Tablo 16. Öğrencinin Aldığı Son Matematik Notu ile Matematik Testi ve Değerlendirilme Kaygısı Arasındaki Regresyon Analizi Sonuçları

\begin{tabular}{|c|c|c|c|c|c|c|}
\hline & \multirow[b]{2}{*}{ Model } & \multicolumn{2}{|c|}{$\begin{array}{c}\text { Standardize Edilmemiş } \\
\text { Katsayılar }\end{array}$} & \multirow{2}{*}{$\begin{array}{c}\begin{array}{c}\text { Standardize Edilmiş } \\
\text { Katsayılar }\end{array} \\
\text { Beta } \\
\end{array}$} & \multirow[b]{2}{*}{$\mathbf{t}$} & \multirow[b]{2}{*}{$\mathbf{p}$} \\
\hline & & B & Standart Hata & & & \\
\hline \multirow[t]{2}{*}{1} & Sabit & ,760 & ,165 & & 4,617 & ,000 \\
\hline & $\begin{array}{l}\text { Matematik } \\
\text { Hususunda } \\
\text { Özgüven } \\
\text { Eksikliği }\end{array}$ & ,488 & ,087 &, 515 & 5,639 & ,000 \\
\hline
\end{tabular}

Bağımlı değişken: Gündelik yaşamdaki matematiksel kaygı. 
$Y=0,760+0,488 * X$ denklemi elde edilir. (X: Matematik Hususunda Özgüven Eksikliği, Y: Gündelik Yaşamdaki Matematiksel Kayg1)

Sonuç olarak günlük yaşamda hissedilen matematik kaygısı arttıkça öğrencinin matematik konusunda özgüven eksikliği de artabilir.

\section{Sonuç ve Tartışma}

Matematik dersindeki başarısızlıkların sebeplerinden biri, öğrencilerin matematik dersine duydukları kaygı olabilir. Eğitim-öğretimde ülkemizde gerçekleşen düzenlemeler, iyileştirmeler, eğitimde kullanılan teknolojilerinin gelişmesine rağmen birçok öğrencinin en baştan matematik dersinin zor olduğunu ve haliyle matematiği başaramayacağını düşünmesi, kaygılanması matematik dersine yönelik tutumunu ve başarısını olumsuz etkilemektedir. Okul dönemi, yılları ilerledikçe bu başarısız olma durumu da artmaktadır. Sonuç değerlendirilmesinde öğrencilerin matematik dersine olumsuz yaklaşması ve tutum sergilemesi aynı zamanda kendilerine güvenin azalmasılyla birlikte matematik dersine yönelik kaygılarının arttığı söylenebilir.

Araştırmaya katılan öğrencilerin, çalı̧̧mamızın birinci alt problemine ait sonuçlar 1şığında matematik kaygı düzeyi normal düzeyde olduğu görülmektedir. Alanda yapılan literatür taraması sonucunda benzer olarak Erktin, Dönmez ve Özel (2006) de ortaokul ve lise öğrencileri üzerinde yaptıkları çalışmada aynı sonuca ulaşmışlardır. Aynı şekilde Dede ve Dursun (2008) ‘un ortaokul öğrencileri üzerinde yapmış oldukları çalışmada da öğrencilerin kaygı düzeyleri orta seviyede saptanmıştır.

Araştırmaya katılan öğrencilerin çalışmamızın ikinci alt problemine ait sonuçlar ışığında ise genel olarak cinsiyet ile matematik dersine yönelik kaygısı arasında anlamlı bir fark görülmemiştir. (Tablo 4, p >.05 ). İlgili literatürler incelendiğinde, aynı şekilde öğrencilerin cinsiyetleri ile matematik kaygısı arasında anlamlı bir farkın olmadığı gözlenmiştir.

Öğrencilerin yapılan çalışmada matematiğe karşı duydukları kaygının bulundukları bölüme göre anlamlı bir fark olmadığı görülmüştür (Tablo 4, p >.05).

Çalışmamızın bir diğer alt problemine ait olan sınıf düzeyindeki değişime göre matematik kaygısına baktığımızda ise, yalnızca sınıf düzeyi ile 'Matematiğe Yönelik Kaygi" alt boyutu arasında anlamlı bir fark olduğu görülmektedir (Tablo 4, p <.05). Buna göre 9.sınıflar ve 11.sınıflar, 12.sınıflara göre matematik dersine karşı daha fazla kaygı duymaktadır. Sonuç olarak lise öğrencilerin sınıf düzeyi arttıkça matematik dersine ilişkin kaygıları azalmaktadır. Yenilmez ve Özbey (2006) tarafından yapılan çalışmada benzer olarak ilköğretimdeki öğrencilerin sınıf düzeylerinin artmasına karşılık olarak matematik kaygı düzeylerinin de azaldığı görülmüştür (Yenilmez ve Özbey, 2006). Bir diğer çalışmaya göre ise yine öğrencilerin sınıf düzeyine göre gördükleri öğrenim ile matematiğe özgü 
yaklaşımları arasında sayısal olarak anlamlı bir fark görüldüğü belirlenmiştir. Araştırmanın sonuç kısmında 11. sınıfta öğrenim gören öğrencilerde matematiğe olan tavır 9 ve 10. Sınıf öğrencilerine nazaran daha pozitiftir (Alkan, Büyükova Güzel ve Elçi, 2004).

Araştırmamızın cevap aradığı son probleme ait sonuçları incelediğimizde öğrencilerin aldığı son matematik notu ile matematiğe karşı duydukları kaygı arasında yalnızca " Matematik Testi ve Testin Değerlendirilmesi Kaygısı" ve "Gündelik Yaşamdaki Matematiksel Kaygı" alt boyutları için anlamlı bir farklılık görülmektedir (Tablo 5, p<.05 ). Buna göre 'kalır' not alan öğrenciler ve 'orta' not alan öğrenciler, 'pekiyi' not alan öğrencilere göre daha fazla matematik sınavı ve değerlendirme kaygısı taşımaktadır. Sonuç olarak öğrencinin matematik sınavı ve değerlendirilme kaygısı arttıkça matematik sınavından aldığı not düşmektedir.

Kaygısı yüksek olan öğrencilerin, düşük olan öğrencilere nazaran daha fazla ders çalışmalarına rağmen, yine daha başarısız oldukları görülmektedir. Elde edilen veriler ışığında, başarısız olmasının sebebi öğrencilerin ders çalışma zamanının azlığından veya fazlalığından kaynaklanmamakta, olumsuz yaklaşım ve düşüncelerinden kaynaklanmaktadır. Bu olumsuz durumun nedeninin kendi üzerlerinde oluşturduğu olumsuz hava ve başa çıkılamaz kaygılarının olduğu görülmektedir (Sekman, 2005).

Yüksek matematik kaygısının başarısızlığa sebep olasılığının yanında fiziksel ve duygusal rahatsızlıklara neden olduğu, öğrencilerin meslek seçimini de kısıtladığ görülmektedir (Fennema ve Sherman, 1976; Hendel, 1980; Erol, 1989; Yüksel Şahin, 2004).

Matematik kaygısı ölçeği; istenilen seviyede iç tutarlığa sahiptir. Rehber danışman ve öğretmenlerce öğrencilerin matematik kaygısını tespit etmek için rahatlıkla tercih edilebilir. Kaygısı yüksek olan öğrencilere bu kaygıyı aza indirmek için program hazırlanır, çalışmalar yapılır. Bunun beraberinde matematik alanındaki bilgi eksiklerini ortadan kaldırmak için destek çalışmaları uygun olacaktır (Tobias, 1978; Baloğlu, 2001; Baloğlu, 2004; Bekdemir, Işık ve Çıkılı, 2004).

\section{Kaynaklar}

Alkan, H., Büyükova Güzel E. \& Nuket Elçi, A. (2004). Öğrencilerin Matematiğe yönelik tutumlarında Matematik öğretmenlerinin üstlendiği rollerin belirlenmesi. XIII. Ulusal Eğitim Bilimleri Kurultayı, 6-9 Temmuz 2004 İnönü Üniversitesi, Eğitim Fakültesi, Malatya.

Baloğlu, M. (2001). Matematik korkusunu yenmek. Kuram ve Uygulamada Ĕ̆itim Bilimleri Dergisi, 1 (1); 59-76.

Baloğlu, M. (2004). Çeşitli başa çıkma yolları ile matematik kaygısı arasındaki ilişki. Eğitim Araştırmaları Dergisi, 16, Yaz. 
Bekdemir, M., Işık, A. \& Çıkılı, Y. (2004). Matematik kaygısını oluşturan ve arttıran öğretmen davranışları ile çözüm yolları. Eğitim Araştırmaları Dergisi, 16, Yaz.

Betz, N. E. (1978). Prevalence distribution and correlates of math anxiety, in college students. Journal of Counseling Psychology, 25 (5); 441-448

Crawford, C. G. (1980). Math without fear. New York: New Visionpoints/ Vision Books.

Dede, Y. \& Dursun, Ş. (2008) İlköğretim II. kademe öğrencilerinin matematik kayg1 düzeylerinin incelenmesi. Ĕ̆itim Fakültesi Dergisi XXI (2), 295-312

Engelhard, G. Jr. (1990). Math Anxiety, mother's education, and the mathematics performance of adolescent boys and girls: evidence from the United States and Thailand. The Journal of Psychology, 124 (3); 289.

Erktin, E. (1993). The relationship between math anxiely attitude toward mathematics and classroom environment. 14. International Conference of Stress and Anxiety Research Society (STAR), Cairo, Egypt, April 5-7 1993.

Erktin, E. (1994). Do Parents attitudes count? Relationship between perceived attitudes of parents toward math and math related attitude, anxiety and achievement of secondary school students. II. International Congress of Adolescentology, Milano 94 Adolescence and Family, Milan, Italy.

Erktin, E. \& Demir-Gülşen, M. (2000). Olasılık konusu ve matematik ders başarısının bilişsel, duygusal ve bilişüstü değişkenlerle ilintisi. IV. Fen Bilimleri Ĕ̆itimi Kongresi Bildirileri, Hacettepe Üniversitesi Ĕ̈itim Fakültesi, Ankara, Eylül 5-7

Erktin, E., Dönmez, G. \& Özel, S. (2006). Matematik Kaygısı Ölçeği'nin Psikometrik Özellikleri. Eğitim ve Bilim, 31 (140); 26-33

Erktin.E. \& Küçük, Ç. Z. (1999). Effectiveness of a math anxiety reduction program for Turkish seventh grade students. 20. International Conference of the Stress and Anxiety Research Society (STAR).July 12-14 1999. Cracow, Poland.

Erol, E. (1989). Prevalence and correlates of math anxiety in Turkish high school students. (Yayımlanmış Yüksek Lisans Tezi). Boğaziçi Üniversitesi, İstanbul.

Fennema, E. \& Sherman, J. A. (1976). Fennema-Sherman mathematics attitude scales: Instruments designed to measure attitudes toward the learning of mathematics by females and males. JSAS Catalog of Selected Documents in Psychology, Vol 6, No:31.

Furner, J. M. \& Berman B.T. (2003). Math anxiety: Overcoming a major obstacle to the improvement of students' math performance. Childhood Education, 79 (3); 170-175.

Hendel, D. D. \& Davis, S. (1978). Effectiveness of an intervention strategy for reducing mathematics anxiety. Journal of Counseling Psychology, 25; 429-434.

Hendel, D. D. (1980). Experimential and affective correlates of math anxiety in adult women. Psychology of Women Quarterly, 5 (2); 219-230.

Richardson, F. C. \& Suinn, R. M. (1972). The mathematics anxiety rating scale: Psychometric data. Journal of Counseling Psychology, 19 (6); 551-554. 
Rounds, J. B. \& Hendel, D. D. (1980). Measurement and dimensionality of mathematics anxiety. Journal of Counseling Psychology, 27 (2); 138-149.

Rounds, J. B. \& Hendel, D. D. (1980). Mathematics anxiety and attitudes toward mathematics. Measurement and Evaluation in Guidance, 13 (2); 83-89.

Sekman, M. (2005). Başarının düşmanı: kaygı! Herşey Seninle Başlar

Suinn, R. M., Taylor, S. \& Edwards, R. N. (1988). Suinn Mathematics Anxiety Rating Scale or Elementary School Students: Psychometric and Normative Data. Educational and Psychological Measurement, 48; 979-986.

Satake, E. \& Amato, P. P. (1995). Mathematics anxiety and achievement among Japanese elementary school students. Educational and Psychological Measurement, 55 (6); 1000 .

Tobias, S. \& Weissbrod, C. (1980). Anxiety and mathematics: An update. Harvard Educational Review, 50 (1); 63-71.

Tabachnick, B.G. \& Fidell L.S., (2013) Using Multivariate Statistics 6th ed., Pearson, Boston

Tobias S., (1978). Overcoming Math Anxiety. New York: Norton Co.

Üldaş, İ. (2005). Öğretmen ve Öğretmen Adaylarına Yönelik Matematik Kaygı Ölçeği (MKÖ-Ö)'nin Geliştirilmesi ve Matematik Kaygısına İlişkin Bir Değerlendirme. (Yayımlamış Yüksek Lisans Tezi). Marmara Üniversitesi Eğitim Bilimleri Enstitüsü, İstanbul.

Yenilmez, K. \& Özbey, N. (2006). Özel okul ve devlet okulu öğrencilerinin Matematik kayg1 düzeyleri üzerine bir araştırma. Eğitim Fakültesi Dergisi, XIX (2); 431-448.

Yıldız, D. \& Uzunsakal, E. (2018) Alan araştırmalarında güvenirlik testlerinin karşılaştırılması ve tarımsal veriler üzerine bir uygulama, Uygulamalı Sosyal Bilimler Dergisi, (1)

Yüksel-Şahin, F. (2004). Ortaöğretim öğrencilerinin ve üniversite öğrencilerinin matematik korku düzeyleri. Ĕ̆ilim Bilimleri ve Uygulama 3 (5). 